\title{
NATIONAL IDENTITY AS A CRISIS CHALLENGE FOR IMMIGRANTS FROM THE EAST OF UKRAINE
}

\section{Shershova Tetiana ${ }^{1}$}

\section{DOI: https://doi.org/10.30525/978-9934-571-89-3_67}

The concept of national identity can be considered through the prism of different approaches, each of which gives this concept a corresponding content load.

National-cultural identity and identification of Ukrainians were considered by I. Bychko, I. Boychenko, O. Hnatyuk, O. Hrytsenko, O. Zabuzhko, M. Zerov, O. Lisovy, M. Ryabchuk, I. Fedorova. Developed this problem as well M. Vyvcharik, M. Hrushevsky, V. Lichkovakh, N. Pogorila, M. Popovich, Yu. Rymarenko, D. Chyzhevsky and others.

Identity and identification issues are among the most important in culturology. It would seem that similar, but completely different concepts. Interest in this issue arose in the late nineteenth century.

From the point of view of psychological knowledge, the concept of identity can project its inner world to other people, see another person as the continuation of himself, his "I", transfer the world of other people into his inner world, reincarnate in them [7, p. 162].

Formation of national identity occurs even in childhood (primary identification) in the family circle and under the influence of the microsocial environment. The child first identifies himself with his mother, and then with his parents, whose gender is recognized as his own. It is precisely this consciousness of the person that is filled with the national content, as a result of which the world is expanding. J. Lacan interprets the primary identification as follows: "Each object relation corresponds to its own identification method, the signal of which serves as an alarm. Such identification is preceded by the identification of its own" [3, p. 94].

According to I. Lebedinskaya: "the intentionality of the cultural identity of a person means its mediation "incivility" in the symbolic topology of the world of culture" [4, p. 258].

O. Nikolayenko uses the term "cultural-national identity" in his study of modern Ukrainian literature, defining it as: "a complex psychological complex of man's representations of his "I" in relation to the cultural tradition of a certain nation with which he identifies himself" and separates three elements of its structure - cultural memory, communication and political component [5, p. 5], and the researcher G. Fayzullina adds to them the mentality, world outlook and discursive measurements of ethno-cultural identities [6].

In Ukraine, in the XXI century, processes of self-identification and self-awareness of its citizens continue to be carried out on their role in society, politics and socio-

\footnotetext{
${ }^{1}$ National Academy of Managerial Staff of Culture and Arts, Ukraine 
cultural environment. In the modern cultural space, the problem of national identity determines the level of socio-cultural dynamics [1, p. 9].

Cultural interaction is now mainly through computer networks and the media, which leads to the erosion of borders between national cultures and changes in the understanding of traditional identities. There are only fragmentary ideas about national culture.

According to T. Kolosok: "At the beginning of the XXI century. Socio-cultural identity in a multicultural world is not guaranteed, but European cultural identity cannot be opposed to national identity, since they correlate with each other on the principle of complementarity" [2, p. 14].

It should be noted that the military conflict in the East of Ukraine led to the fact that a significant number of Ukrainian citizens were forced to leave their homes and move to another area where administrative services were provided and conditions were created for better adaptation to new living conditions during hostilities in the occupied territory. It is important, under such conditions, to preserve the integrity and national identity of the displaced families, which constitute a significant part of society, and therefore the nation. Unfortunately, in such an environment there are controversial questions about their own belonging to the state, though opinions are somewhat disconnected, and identity issues are retreating into the background, in acutely crisis conditions. This leads to marginalization - the loss of cultural identity, since settlers partly integrate into another regional culture.

A productive way out of such a situation is to preserve the national cultural core and its development on the basis of new cultural ideas and directions.

The basis of national and cultural identity is the self-identification of a person, the definition of their own belongings in the process of obtaining ethno-cultural information, the search for archetypes, ideas, cultural invariants. People fix their own socio-cultural identity with certain characters - language, religion, history, way of life, clothing style, customs and rituals, songs and dances.

Internally displaced persons lose part of their own culture, leaving the occupied territories. On the foreground of the citizens are the problems of registration, housing, food, social benefits, ensuring the standard of living of their family, services for the protection of life and health. This leads to a state of maladaptation, people often remain alone with their problems in the new living conditions. They break the relationship with the environment, isolating themselves in their internal, full of conflicts, the world. Ukrainian society at the same time tries to solve several urgent tasks: the formation of civil society, the creation of a national idea and the preservation of the state. The condition of their solution is the question of the formation of a national identity.

In today's situation, when Ukraine is in an unstable situation, self-identification is very important as a worthy citizen must clearly understand his place in society and identify himself in new, political, economic and cultural conditions.

The adoption in the state of ethno-national values through transformational changes will lead to the prospects for Ukraine's development, as well as its emergence on the international level. Understanding the individual and the society in 
which he belongs, his own position in the state and society is possible provided that the historical and cultural memory is restored.

In modern conditions, essential changes occur in the socio-cultural space and the formation of a national identity of the individual. Man, as a social being, is in constant interaction with the surrounding world, with other people and continuously identifies himself with different social groups, defines his status in society, his attitude to one or another event. Maximum consideration of historical experience and the creation of complex methods for the study of ethno-national identity will contribute to the procedural nature of the concept being studied.

\section{References:}

1. Denysiuk Zh. (2010). Mass culture as a factor of the transformation of national-cultural identity in the conditions of globalization : Author's abstract Dis.. Cand. of Cultural Studies. Sciences : special 26.00.01 "Theory and history of culture". K. : NAKKKiM. (in Ukrainian)

2. Kolosok T. (2009). Socio-cultural identity in conditions of European integration (on the example of Ukrainian-Czech cultural relations) : Author's abstract Dis.. Cand. of Cultural Studies. Sciences : special 26.00.01 "Theory and history of culture". K. : National Music Academy of Ukraine named after P. I. Tchaikovsky. (in Ukrainian)

3. Lakan Zh. (1998). Seminars. Book 1. Freud's work on the technique of psychoanalysis. (1953-1954) / Per. fr fr M. Titova. M. : Logos. (in Russian)

4. Lebedynska I. (2011). Culture as a way of acquiring identity: methodological reflection. Methodological problems of cultural anthropology and ethnocultural studies. K.: Institute of Cultural Studies of the National Academy of Sciences of Ukraine. (in Ukrainian)

5. Nikolaienko O. (2015). Cultural and national identity in the context of modern Ukrainian literature : Author's abstract Dis.. Cand. of Cultural Studies. Sciences : special 26.00.01 "Theory and history of culture". (in Ukrainian)

6. Faizullina H. (2017). Ethno-cultural Dimensions of Ukrainian Philosophic Novel : Author's abstract Dis.. Cand. of Cultural Studies. Sciences : special 26.00.01 "Theory and history of culture". K. : NAKKKiM. (in Ukrainian)

7. Cherniienko V. (2006). Identity and metaphysics. Science. Religion. Society. Vol. 4. (in Ukrainian) 